\title{
HAK WARGA NEGARA DI BIDANG SOSIAL DAN BUDAYA PADA PENDIDIKAN
}

\author{
Resty Nurqomah \\ 2010128220014@mhs.ulm.ac.id \\ Program Studi Pendidikan IPS Fakultas Keguruan dan Ilmu Pendidikan \\ Universitas Lambung Mangkurat
}

\begin{abstract}
Abstrak
Hak Asasi Manusia ialah hak dasar khusus pasti dimiliki dan menempel di individu. Bersifat umum serta diharuskan melindungi adanya peraturan hingga tidak bisa diambil apalagi dikurangi karena, kodratnya harus dipertahankan hak itu bagaimanapun juga. Di Indonesia di bagian XA adanya memuat perubahan di UUD 1945 yang menggambarkan hak asasi manusia. Salah satunya pada hak sosial kebudayaan, tetapi tidak secara jelas dan rinci. Yang masih tersebar di Pasal Perubahan Undang-Undang Dasar pada tahun 1945. Permasalahan budaya ialah seluruh sistem maupun tata nilai berupa perilaku jiwa, cara berpikir, perilaku, pada bermacam keseharian yang tidak mencukupi untuk warga negara dengan totalitas, alias dibicarakan kalau permasalahan kebudayaan ialah susunan hasil yang bisa memunculkan permasalahan kritis masyarakat, hendak menimbulkan "dehumanisasi" ataupun terjadinya kurungan pada seorang. Permasalahan memenuhi bermacam hidup warga negara keseluruhan yang menggambarkan pengungkapan permasalahan manusia serta kebudayaan.
\end{abstract}

Kata Kunci: Hak asasi manusia, Hak asasi sosial Budaya, Warga negara

\section{Pendahuluan}

Menurut Mariam Budiardjo, HAM merupakan hak dipunyai individu dengan sudah memperoleh serta pembawaan yang bertepatan dengan lahir serta 
hadir pada kehidupan warga. Terdapat di individu dengan tidak ada perbedaan ras, bangsa, keagamaan, kalangan, tipe jenis kelamin, sebab bertabiat juga umum. Seluruh warga negara, di mana seluruh warga wajib mendapatkan peluang dalam mengembangkan bakat serta cita-citanya. (Mariam Budiardjo, 1982: 120). UU Republik Indonesia nomor 39 pada 1999, menyebutkan Hak asasi manusia ialah dasar menempel di hakekat adanya individu atau manusia, selaku makhluk Tuhan Yang Maha Esa dengan dihormati, dijunjung, juga dilindungi hukum, pemerintah, negara. Dengan tiap individu menjaga demi proteksi serta kehormatan harkat serta martabat individu. Hak asasi manusia dituturkan "Droit LHomme", "hak-hak manusia" serta dituturkan "Human Rights".

Bersama pada berkembangnya pengajaran Negeri Hukum, yang individu maupun kelompok memiliki hal basic center haruslah dilindungkan oleh pemerintahan. Timbulnya "Basic Rights" maupun "Fundamental Rights". Yang diubah ke bahasa Indonesia, menggambarkan sesuatu yang bersifat awal individu maupun terkenal sebagai "Hak Asasi Manusia" (Ramdlon Naning, 1982: 97). Penafsiran hak warga negara selaku hak hukum memiliki penafsiran keseluruhan, tidak hanya hak alami maupun moral, namun juga hak hukum terbuat dari tubuh negeri. Diartikan hak bicara dengan menimpa HAM sesuai yang dimaksudkan di area kondisi ataupun wilayah kebebasan berperan. Dalam pemerintah tidak adanya mengadakan pembatasan, sampai membiarkan kepada kelompok maupun individu buat memilah sendirinya. Hak asasi manusia pada sosial budaya merupakan hak yang memiliki hubungan dengan adanya kehidupan bermasyarakat yaitu, hak dalam memilih, mendapatkan, juga dalam menentukan pendidikan.

\section{Metode Penelitian}

Dalam pendekatan penataan ini berbentuk kualitatif, jadi data disusun menggunakan buletin ataupun harian serta dokumen resmi yang lain. Taylor dan Bogdan menyebutkan bahwa penataan kualitatif dapat diartikan penataan kualitatif dimaksudkan penataan yang hasilnya berupa deskriptif tentang kata yang lisan ataupun tulis, serta perilaku bisa dilihat dari kelompok peneliti. Pengumpulan data dan informasi mengenakan penulusuran pustaka dan 
pencarian sumber-sumber relevan melalui internet, dari media elektronik berupa buletin ataupun harian dan dokumen yang lain. Dengan salah satu cara mengumpulkan data ialah, dikumpulkan dari berbagai referensi, baik jurnal, artikel dan lainnya sehingga akhirnya akan berbentuk tulisan diartikel ini.

\section{Hak Asasi Manusia bidang Sosial serta Budaya}

Pada hak sosial dan budaya sama pada Basic Humanities, di mana Humanities "human", "manusiawi", "berbudaya" serta "berbudi halus" (refined) yang diharapkan seorang menekuni Basic Humanities bukanlah persis pada pembelajaran kebudayaan dengan berhubungan keterampilan filsafat serta seni. Dalam susunan hal dasar social science kebudayaan harus sesuai perlengkapan dengan mendekati serta memecahkan permasalahan muncul serta tumbuh pada warga. Sehingga social science dan kebudayaan membagikan cara dari sisi lain dalam memecahkan permasalahan sosial kebudayaan kelompok. Bersumber pada uraian ditemukan suatu social science kebudayaan, di mana peserta didik bisa buat berikutnya mengenali kemana dalam memecahkan permasalahan. Pada hak bersosial dan kebudayaan mengkaji permasalahan di masyarakat, manusia serta kebudayaan, sekalian mendekatkan pada sumber dasar social science.

Ruang lingkup hak sosial dan budaya memuat masalah, seperti:

1. Pada aspek kehidupan secara keseluruhan dengan mengungkit sebuah ungkapan pada permasalahan manusia dan juga budaya dengan pendekatan menggunakan ilmu pendidikan kebudayaan, pada segi ahli dan pendidikan kebudayaan ataupun melalui campuran dari beberapa disiplin pendidikan kebudayaan.

2. Pada hakikat individu secara umum tapi juga bermacam-macam, di wujudkan pada kebudayaan secara lokasi atau waktu.

Hubungannya pada kehidupan sehari-hari, yaitu:

1) Dengan kebiasaan serta minat untuk menyelidiki yang mungkin ada apa yang terjadi di sekitar lingkungan juga di luar lingkungan tersebut.

2) Dengan kekuatan dalam meyakini hasil dirasa bisa diterima berupa tanggung jawab, juga kebalikannya bisa memberi penolakan hasil dirasa kurang benar. 


\section{Hak Asasi Manusia bidang Sosial}

Hak manusia di sosial merupakan hak warga negara memilki jaminan masyarakat, memiliki rumah serta mendapat pembelajaran, ditetapkan:

1. Pasal $28 \mathrm{H}$ ayat tiga, Perubahan Undang-Undang Dasar 1945 memastikan: Tiap individu memiliki hak pada jaminan masyarakat atau sosial dengan membolehkan mengembangkan individu menyeluruh selaku individu atau manusia yang memiliki martabat.

2. Pasal $28 \mathrm{H}$ ayat satu, Pergantian Undang-Undang Dasar 1945 memastikan: Tiap individu memiliki hak sejahtera dalam kehidupan baik lahir serta batin, memiliki tempat tinggal, serta memperoleh area kehidupan yang nyaman serta diberi kesehatan dan mendapatkan pelayanan dalam kesehatan.

3. Pasal 31, Pergantian Undang-Undang Dasar 1945 memastikan mengenai pembelajaran serta budaya ialah:

a. Ayat pertama, Tiap masyarakat Negeri memiliki hak mendapatkan pembelajaran.

b. Ayat kedua, Tiap masyarakat Negeri harus menjalani pembelajaran dasar serta pemerintah harus membiayainya.

c. Ayat ketiga, pemerintahan harus berusaha serta melaksanakan sistem pembelajaran negara, sehingga dapat menaikkan iman juga takwa dan akhlak baik pada hal membuat cerdas bangsa negara sesuai pada UU.

d. Ayat keempat, Negeri mengutamakan kebutuhan pembelajaran sekurangnya $20 \%$ pada anggaran pemasukan serta pembelian negeri, pada anggaran pemasukan serta pembelian wilayah buat penuhi keperluan pelaksanaan pembelajaran negara.

e. Ayat kelima, pemerintahan mengembangkan pengetahuan serta teknologi, buat bangsa negara mengalami pertumbuhan kehidupan dan sejahteranya individu atau warga negara.

\section{Hak Asasi Manusia bidang Budaya}

Hak asasi individu pada bidang kebudayaan atau budaya bisa dibagi pada:

1. Pasal 28 C, Pergantian Undang-Undang Dasar 1945 memastikan kalau: Tiap manusia memiliki hak meningkatkan dirinya lewat terpenuhi kebutuhan 
dasar, memiliki hak menemukan pembelajaran serta mendapatkan arti pengetahuan juga teknologi, kebudayaan juga suatu seni, untuk menaikkan mutu hidup kesejahteraan masyarakat.

2. Pasal 28 I ayat tiga, Pergantian Undang-Undang Dasar 1945 memastikan kalau: Bukti diri budaya serta hak warga terdahulu atau tradisional diberi hormat sama pada pertumbuhan era serta kehidupan.

3. Pasal 32, Pergantian Undang-Undang Dasar 1945 memastikan:

a. Ayat pertama, Negeri mengembangkan budaya negara Indonesia secara nasional di antara kehidupan internasional, beserta jaminan adanya hak bebas warga negara melindungi serta meningkatkan hasil kebudayaan.

b. Ayat kedua, Negeri memiliki rasa hormat serta melindungi bahasa wilayah selaku beragamnya kebudayaan negara.

\section{Hak Sosial dan Budaya pada Pendidikan}

Dalam hal pendidikan pada UU Republik Indonesia 2003 mengenai Sistem Pembelajaran atau Pendidikan Nasional adalah hukum untuk menyelenggarakan dan mereformasi sistem pembelajaran atau pendidikan nasional. UU memuat adanya visi, misi, tujuan, dan fungsi pada pendidikan secara relevan, bermutu sehingga sesuai dengan yang dibutuhkan masyarakat dengan berdaya saing yang baik pada kehidupan arus globalisasi. Dalam visi pendidikan Indonesia adanya ingin mewujudkan susunan pembelajaran pada masyarakat sangatlah besar serta juga memiliki wibawa dalam menuju pemberdayaan seluruh masyarakat sehingga dapat berkembang dan tumbuh sebagai manusia yang memiliki kualitas serta produktif pada saat menjawab atau menghadapi tantangan yang selalu berbeda di setiap zamannya di karenakan zaman yang selalu berubah. Di mana tidak akan lagi ada arti mengenal adanya batasan di setiap antar negara baik dari segi ruang ataupun pada segi waktu. Selaku pada kebudayaan serta kehidupan individu, pembelajaran bermacam di negeri nasional hadapi pergantian awal masa global. Di masa globalisasi ini sangatlah meningkat perkembangannya, baik pada ilmu pengetahuan dan juga pada teknologi.

Yang di mana semua itu akan dapat menolong individu atau kelompok baik secara langsung ataupun daring di sekitar antar daerah ataupun antar 
negara. Dalam masa globalisasi saat ini, pembelajaran telah jadi komoditas yang kian menarik. Pembelajaran dimaksudkan untuk mempersiapkan bangsa menuju masa yang akan datang serta membuat warga negara memiliki martabat di bangsa lainnya seluruh dunia. Masa yang akan datang senantiasa tumbuh dalam pembelajaran membiasakan individu berproses demokrasi serta membangun bangsa. Dalam masa globalisasi, persaingan bakal terus menjadi ketat, sehingga sangat diperlukan kebijakan serta aktivitas secara langsung. Jika kita perhatikan di masa globalisasi diperlukan bentuk dari diri kita, apakah bisa diterima keberadaan di sebagian negara ataupun, pada persiapan surat nasional atau sertifikat. Di masa globalisasi ini tidak cukup hanya pada sertifikat Nasional, tetapi kita juga memerlukan sertifikat internasional selaku diakui atas kemampuan warga negara pada tingkat dunia, hingga bisa menyusuri negeri yang diinginkan sesuai surat atau sertifikat yang dipunya.

\section{Simpulan}

Dalam hak sosial dan budaya mengkaji permasalahan masyarakat, kebudayaan serta individu, sekalian pada member awal dengan mendekati pada dasar social science terintegrasi. Hak manusia pada bidang sosial merupakan HAM berhubungan pada jaminan sosial, hak pada rumah serta hak pada pembelajaran. Pendidikan pada Undang-Undang Republik Indonesia 2003 mengenai Sistem Pendidikan Nasional adalah hal suatu hukum untuk menyelenggarakan dan mereformasi sistem pembelajaran atau pendidikan nasional. Pada UU memuat adanya visi, misi, tujuan, dan fungsi pada pendidikan secara relevan, bermutu sehingga sesuai dengan yang dibutuhkan masyarakat dengan berdaya saing yang baik pada kehidupan arus globalisasi. Di masa globalisasi ini sangatlah meningkat perkembangannya, baik pada ilmu pengetahuan dan juga pada teknologi, yang di mana semua itu akan dapat menolong individu atau kelompok baik secara langsung ataupun daring di sekitar antar daerah ataupun antar negara. Dalam masa globalisasi saat ini, pembelajaran telah jadi komoditas yang kian menarik.

\section{Referensi}

Budiardjo, M. 2019. Dasar-Dasar Ilmu Politik, Edisi revisi. Jakarta: PT Gramedia Pustaka Utama 
Firdaos, R. (2015). Orientasi Pedagogik Dan Perubahan Sosial Budaya Terhadap Kemajuan Ilmu Pendidikan Dan Teknologi. Al-Tadzkiyyah: Jurnal Pendidikan Islam, 6(1), 106-117.

Manusia, K. N. H. A. (1997). Hak Asasi Manusia. Gramedia Pustaka Utama, Jakarta.

Nasution, M., Daulay, M., Susanti, N., \& Syam, S. (2015). Ilmu sosial budaya dasar.

Putra, M. A. H. (2019). Building Character Education Through The Civilization Nations Children. The Kalimantan Social Studies Journal, 1(1), 12-17.

Subawa, I. M. (2008). Hak Asasi Manusia Bidang Ekonomi Sosial Dan Budaya Menurut Perubahan UUD 1945. Kertha Patrika, 33(1).

Umanailo, M. C. B., Sos, S., Umanailo, M. C. B., \& Sos, S. (2016). Ilmu sosial budaya dasar.

Universitas Islam Indonesia (Yogyakarta). Pusat Studi Hak Asasi Manusia (PUSHAM), Smith, R. K., Asplund, K. D., \& Marzuki, S. (2008). Hukum hak asasi manusia. Pusat Studi Hak Asasi Manusia, Universitas Islam Indonesia (PUSHAM UII). 